\title{
Strengthening music provision in early childhood education: A collaborative self-development approach to music mentoring for generalist teachers ${ }^{1}$
}

\author{
Margaret S. Barrett, Katie Zhukov \& Graham F. Welch
}

\section{Abstract}

This paper reports an evaluation of a pilot program of workplace music mentoring for generalist classroom teachers in eleven early childhood education settings in Australia. Mentoring in the arts in general and in music specifically is still under-researched despite a considerable body of literature on approaches to mentoring, and descriptions of mentoring practices and outcomes. The pilot program documented here was created to increase access to music education for Australian children through establishing mentoring relationships between experienced specialist music teachers and generalist classroom teachers. The program aimed to address a lack of music training during undergraduate teacher preparation and a perceived lack of confidence in music teaching and singing amongst generalist classroom teachers. The evaluation of the mentoring program included semi-structured interviews with ten principals, seven mentors and nineteen mentees regarding their experiences. Three researchers conducted the thematic analysis of transcripts independently and refined the emerging themes through iterative discussions. The findings demonstrate that the workplace music mentoring delivered positive outcomes, enriching schools' music curricula, structuring locally relevant programs, building resources, teacher music skills and confidence, and impacting positively on student learning and behaviour. The in-situ longitudinal mentoring model implemented expands on traditional approaches to professional development for in-service teachers of music through a collaborative self-development approach.

\section{Introduction}

\section{Music provision in primary education: The Australian context}

Music education has a long history as an independent subject in the curricula and syllabi of Australia's six states and two territories. In the last decades, however, music education's place in the Australian curriculum landscape has retracted (DEST 2005). This may be attributed to a range of factors, including: the location of music as one of five components (dance, drama, media, music, visual arts) in The Arts Key Learning Area (see the Hobart declaration (MCEECDYA 1989),

To cite this article: Margaret S. Barrett, Katie Zhukov \& Graham F. Welch (2019): Strengthening music provision in early childhood education: a collaborative self-development approach to music mentoring for generalist teachers, Music Education Research

To link to this article: https://doi.org/10.1080/14613808.2019.1647154 
the Adelaide declaration (MCEECDYA 1999), and the Melbourne declaration (MCETYA 2008), rather than a stand-alone subject; competing curriculum priorities, with STEM subjects dominating educational policy-making and practice (see the Australian National Innovation and Science Agenda 2015, http://www.innovation.gov.au); a decline in the provision of specialist music education at state and territory levels (DEST 2005); and, a significant decline in the allocation for music education in the preparation of generalist early childhood and primary teachers (Collins, 2016; Hocking, 2009).

Australians' concern about the role and place of Music and the Arts in schooling is evidenced in the successive implementation of a Senate Inquiry into Arts Education in 1995, an Australian Council for the Arts national survey of Australian's attitudes towards the arts in 1999 (Costantoura 2000), a National Review of School Music Education (DEST 2005) undertaken in 2005. This review suggested that provision for music education was unevenly distributed across the country and a cause for national concern. This document coupled with a National Review of the Visual Arts in Australian Schools (MCETYA 2007) became a catalyst for the placement of The Arts as a learning area in phase two of the recent national curriculum project (2009-2014), Australia's second attempt to arrive at a unified national curriculum.

The National Review of School Music Education report (DEST 2005) provided a troubled picture of music education provision and quality across the country. The analysis of a stratified sample of 525 schools and an additional sample of 147 "effective music" schools demonstrated that students in approximately 900 Australian schools had no access to music education - "The National Survey of Schools showed that there are students in approximately 900 Australian schools (about 9-10\% of schools) that have no music programme" (DEST 2005: 144). Where music education was provided, this ranged from a sequential developmental program across the years of schooling to a series of un-related activities that had only loose connection to music education. A consistent theme throughout the report was the reduced time allocated to Music and the Arts in schooling, and teachers' diminished experiences of these curriculum areas in teacher education. Arguably, the gradual reduction in time allocated to Music and the Arts in teacher education over the last decades has led to a comparable reduction in graduating generalist teachers' confidence and competence in implementing music education in their classrooms - a common theme in research findings with generalist teachers in other countries (Hennessy 2000, 2012; Ruddock and Leong 2005; Stunell 2006; Seddon \& Biasutti, 2008).

In response to this increasingly bleak situation, eminent Australian music educator [Dr Richard Gill AM] devised a program of music mentoring, [name withheld for review]. The program aims to develop practising generalist early childhood ( $\mathrm{K}-$ Year 2, ages 5-8y) teachers' knowledge and skills in music education and their capacity to lead music education experiences in their classroom. In its first iteration (2015), the program paired specialist music teachers with generalist classroom teachers in negotiated mentoring relationships. The program has secured considerable support from the Australian Federal Government, with initial funding for a three-year implementation nationally $(2015-17)^{i}$. The program was trialled in two states in $2015^{i i}$. This article reports on the 
impact of the mentoring program on these school communities through the perspectives of the principals, teachers being mentored and mentors who participated in the pilot.

\section{Workplace mentoring approaches}

Workplace mentoring has been described as the relationship between an experienced individual (the mentor) and a less experienced individual (the mentee) in the workplace that aims to assist the personal and professional growth of the mentee (Kram 1985). Workplace mentoring typically takes place over extended periods of time and is multi-faceted in structure (Eraut 2011). Within education workplace mentoring is of particular relevance as contemporary teaching practice involves highly complex curricula and a diverse student body (Martinez 2004). Recognising this Devos (2010) advocates for mentoring within the school workplace together with reduced teaching workloads to help new teachers become established. Referring to music specifically, Jacobs (2008) proposed a pyramid model for effective music mentoring in the workplace which recognises multiple partners and factors in the process including state government design and funding at its base, through to professional organization support, mentor selection, training and compensation, mentor and mentee release time, multi-year concept, and at the top of the pyramid the certification requirement.

Kemmis et al. (2014) identified three main approaches to mentoring - supervision, support and collaborative self-development. Supervision approaches are employed in teacher education where student teachers work with experienced professionals during practica and internship experiences. In mentoring as support, newly qualified teachers are helped by more experienced teachers to develop their professional practice (Langdon et al. 2016). Positive factors in mentoring as a supportive professional development approach include the mentor not being in a power relationship with the mentee, and the approach facilitating acquisition of relevant skills in-situ, leading to situated learning (Kemmis et al. 2014; Lave and Wegner 1991). In collaborative selfdevelopment approaches to mentoring, mentor and mentee conduct professional discussions as equals, leading to mutual growth.

\section{General approaches to effective mentoring of teachers}

The quality of mentoring has been highlighted as being more important to the success of early career teachers than the frequency of mentoring (Richter et al. 2013) with quality mentoring reported to "foster the growth of teacher efficacy, teaching enthusiasm, and job satisfaction" (Richter et al. 2013, 166). Martinez (2004) echoes these sentiments by emphasising the role of mentoring in teacher retention and invigoration of teaching. Richter cautions against transmissionoriented mentoring approaches, arguing that these tend to proliferate new teachers' beliefs in the value of knowledge transmission and do not build teachers' confidence (Richter et al. 2013). Taking these issues into consideration, he suggests that mentoring approaches need to include "opportunities for reflection, experimentation with different teaching methods, and autonomous decision making" (Richter et al. 2013, 174). Hargreaves and Fullan (2012) echo this view by explaining that a good mentor gives feedback and triggers reflection on what the teacher is doing, why they are doing it in a particular way, and how this can be improved. This approach builds "a reciprocal relationship, produces developmental benefits, and involves regular/consistent 
interaction" (Haggard et al. 2011, 292-293). Such approaches create collaborative cultures, where "failure and uncertainty are not protected and defended, but instead are shared and discussed with a view to gaining help and support" (Hargreaves and Fullen 2012, 113).

Sundli (2007) suggests that a positive mentoring approach is a conversation based on written documents and practical tasks, linking theory and practice and promoting reflection. This mentoring approach aims to help new teachers with "strategic planning, training of practical skills, and the development of professional competencies" (Orland-Barak 2014, 180). Mentoring has been identified as playing a significant role in teacher retention and satisfaction with the key aspects being "...having a mentor from the same field, having common planning time with other teachers in the same subject or collaboration with other teachers on instruction, and being part of an external network of teachers" (Smith and Ingersoll 2004, 706). It has been suggested that some of the difficulties of face-to-face mentoring could be lessened through virtual mentoring of pre-service teachers via Skype (Reese 2015). The benefits of using technology for mentoring include time saving on travel for observations and meetings, thus allowing more time for reflection and discussions; greater professional development due to mutual observations by mentor and students; and more opportunities to reflect on growth. However, virtual mentoring limitations involve lack of real-time interaction and lower flow of energy due to two-dimensional technology filtering (Reese 2015).

\section{Effective mentoring of music teaching}

Studies internationally have suggested that music mentoring requires its own unique approaches that combine discipline-specific knowledge with music-teaching strategies. For example, in the USA, it has been reported that generic mandated mentoring programs are routinely applied in a music setting and are viewed by new music educators as ineffective and inconsistent in standards (Benson 2008; Conway 2015). Conway (2015) advocates the need for music teachers to be mentored by music mentors. Mentoring of novice music teachers might include induction into music teaching strategies and classroom routines, lesson planning and assessment, classroom management, pacing, thus leading to development of new views of self (Conway 2008; Conway and Hodgman 2006; Schmidt 2006, 2008). Combinations of practical teaching together with a variety of mentoring approaches (vertical - from music educators and ensemble director; horizontal - from peers, students and community members; and self-mentoring - reflection-onaction and reflection-in-action) served as a thorough practicum preparation for pre-service music teachers involved in a USA string project (Davis 2016). Another novel approach to teaching practicum of undergraduate music education students trialled in Ireland involved coteaching with experienced classroom teachers who had no music training. This study documents positive outcomes for both pre-service music teachers and generalist classroom teachers, with both groups gaining content, pedagogical, curricular, and pedagogical content knowledge (Kerin and Murphy 2015). Peer-mentoring is also an effective means of helping new music educators to settle into teaching music, even if they are already experienced teachers in other subject areas (Blair, 2008; Draves \& Koops, 2011) 
The UK Government's National Singing Programme Sing Up provided another model of music workplace mentoring with a specific focus on the development of singing in both students and their teachers. One major strand of this programme included a cascade model of mentored workforce development (national to regional to local) that was focused on both primary school teachers and community musicians who worked with children. An extensive evaluation of this strand with over 1000 respondents (Himonides et al. 2011) revealed that the workforce development experience was perceived as positive and increased with the number of sessions attended. Furthermore, respondents reported increased confidence and knowledge, as well as a related positive impact on their children's singing behaviours and development. Similarly, a recent evaluation of workplace collaborative mentoring in pre-school settings in London (UK), with a focus on music and speech, language and communication, reported positive impacts on mentors, mentees and children (Welch \& Bowmer, 2017).

\section{Effective mentor qualities}

Effective mentoring with "generally good faith efforts by all parties" fosters new personal and professional relationships (Langdon et al. 2016, 159) with positive mentoring outcomes for both mentors and mentees (Ehrich et al. 2004). For mentors, positive outcomes included collegiality (collaboration, networking, sharing ideas and knowledge), reflection, professional development and personal satisfaction (reward, growth) (Powell, 2018). For mentees, the beneficial impacts included support (empathy, encouragement, counselling, friendship), help (with teaching strategies, subject knowledge and resources), discussion (sharing ideas, information, problems, advice from peers), and feedback (positive reinforcement, constructive criticism) (Ehrich et al. 2004). Effective mentor qualities in music include: strong knowledge of subject matter; compatible philosophy of music education; excellent music and teaching skills; being a good listener, organised, personable, and professional (Conway and Hodgman, 2006). The capacity to nurture and affirm (Smith, 2005) is also identified as a key element of effective mentoring in music.

Much of the mentoring research discussed above is focused on novice teachers embarking on their professional careers (see Benson, 2008; Blair, 2008; Conway, 2005; Devos, 2010, Draves \& Koops, 2011 Hamel, Jasloo \& Fisher, 2011; Hennessy, 2000; Kemmis et al., 2015; Kenny, Finneran \& Mitchell, 2015; Kerin \& Murphy, 2015; Martinez, 2005; Reese, 2015; Richter et al., 2013). Less is known of effective models and outcomes of mentoring for established teachers (such as generalist early childhood education teachers) when embarking on a new disciplinary area (music). The literature highlights the long-term lack of discipline-specific training in music during undergraduate study (in Australia), resulting in teachers being inadequately prepared to teach music. One way of overcoming this barrier is to introduce workplace mentoring of classroom teachers by music specialists. This paper reports on the impact of one such program in Australia.

The following questions underpinned the research:

1. What are the reported outcomes for mentors, teachers and students?

2. What are the qualities of effective music mentoring?

3. What are the qualities of an effective music mentor? 


\section{Methodology}

\section{Study context}

In 2015 Dr Richard Gill AM initiated the National Music Teacher Mentoring Program (NMTMP) in which experienced specialist music educators mentored early childhood (K-2) classroom teachers in their workplace. The program began with a call for volunteer mentors and mentees. Mentors participated in a 2-day workshop that addressed mentoring skills and the music program content. During the Master Class mentors were tutored on the fundamentals of mentoring, and shared simple strategies, practices and resources for engaging students in effective music education. A similar approach to training of mentors has been implemented in the USA (Berg and Conway 2016). Mentors subsequently worked with generalist classroom teachers in a one-to-one mentoring relationship over an extended period of time, being two school terms in New South Wales (20 weeks) and one school term in Victoria (10 weeks). The mentors visited the allocated schools and assessed local resources; invited mentees to observe mentors' music teaching; collaborated in developing music lesson plans and activities that addressed individual teacher goals, needs and context; co-taught music with mentees during classroom lessons; and observed and provided feedback on the mentees' music teaching. Music curricular content was essentially voice-based, with a literacy focus, and included simple instrumental work that was informed by Kodaly and Orff principles.

The mentoring was implemented across two Australian states in 2015. After obtaining ethical clearances ${ }^{\mathrm{iii}}$, researchers 1 and 2 visited participating schools at the end of the mentoring process and interviewed principals, mentees and their mentors, and children, regarding the impact of the program. This paper reports on the perceptions of principals, mentees and mentors. The impacts of the program on student singing outcomes and perceptions are reported elsewhere (see Barrett et al. 2018).

\section{Participants}

The data were generated in eleven schools across the two States, in both urban and regional locations, and across a full spread of socio-economic areas ${ }^{\mathrm{iv}}$, including: schools from disadvantaged areas with a socio-economic index of 1-3, moderately advantaged areas (socioeconomic index 4-6) and highly advantaged areas (socio-economic index of 8-10). The data analysed in this paper consist of ten interviews with principals (or their representatives), seven mentor interviews, and nineteen mentee interviews (see Table 1), totalling approximately 40 hours of data. 
Table 1: Summary of collected data

\begin{tabular}{cccccc}
\hline $\begin{array}{c}\text { School } \\
\text { ID }\end{array}$ & $\begin{array}{c}\text { Socio-economic } \\
\text { decile }\end{array}$ & $\begin{array}{c}\text { Students } \\
\text { enrolled }\end{array}$ & $\begin{array}{c}\text { Mentor } \\
\text { interviews }\end{array}$ & $\begin{array}{c}\text { Teacher } \\
\text { interviews }\end{array}$ & $\begin{array}{c}\text { Principal } \\
\text { interviews }\end{array}$ \\
\hline School 1 & 6 & 60 & 1 & 1 & 1 \\
School 2 & 8 & 700 & & 2 & 1 \\
School 3 & 10 & $700+$ & 1 & 0 & 0 \\
School 4 & 4 & 600 & & 3 & 1 \\
School 5 & 1 & 180 & 1 & 2 & 1 \\
School 6 & 2 & 135 & & 1 & 1 \\
School 7 & 9 & 400 & 1 & 2 & 1 \\
School 8 & 3 & 400 & 1 & 1 & 1 \\
School 9 & 4 & 90 & & 1 & 1 \\
School 10 & 4 & 400 & 1 & 3 & 1 \\
School 11 & 8 & 330 & 1 & 3 & 1 \\
Total (N=36) & & & 7 & 19 & 10 \\
\hline
\end{tabular}

\section{Interviews}

Interviews with principals focused on music provision in their schools, the role of classroom teachers and music specialists, changes observed due to the mentoring program in the mentee participants and their students, impact on learning, parental feedback and recommendations for future implementations of the program.

Mentor interviews explored their motivation to participate in the program, previous mentoring experience, prior mentoring activities and strategies, feedback on the mentoring Master class, background as a music teacher, challenges of the mentoring process encountered during the program, key events that occurred, changes in the mentees' teaching practice, impact on students, music teaching resources and ideas for future development.

Mentee interviews investigated the reasons for participating in the program, prior experience of music and music teaching, previous mentoring experience, changes in use of music in the classroom due to mentoring and its impact on students, challenges experienced during the program, key events, music teaching resources developed and feedback on the program.

\section{Analysis}

The semi-structured interviews were audio-recorded, transcribed by a professional company and the transcripts analysed for emerging themes (Creswell 2015). The analyses followed the procedures for coding and analysis developed by Saldana (2014). The 36 interviews were initially coded by Researchers One and Two individually and the emerging categories refined through iterative discussions "to cluster similar codes into groups for pattern construction and further analysis" (Saldana 2014, 587). Researcher Three reviewed these categories "to propose connections within, between and among the constituent elements of analyzed data" (Saldana $2014,588)$. Further discussions among the three researchers led to "summative findings and evaluative conclusions" (Saldana 2014, 588). These procedures were followed in order to address 
trustworthiness of findings highlighted by Lincoln (2004) as an essential element of qualitative research. The use of participant quotes helps to illustrate how the categories and themes were articulated and enhances the trustworthiness of reported results (Given and Saumure 2008).

The analyses helped to identify themes addressing each of the research questions and to theorise regarding the relevance of real-life experiences reported by the participants to the workplace music mentoring of classroom teachers as recommended by Braun and Clarke (2006).

\section{Findings}

The themes that emerged from the analyses of interviews are documented below under the relevant research questions and illustrated by comments from a range of participants.

\section{Research question one: What are the reported outcomes for mentors, teachers and students?}

\section{Theme 1: Music mentoring as collaborative self-development}

The mentoring approach teamed two experienced professionals with differing areas of expertise (generalist classroom teaching and specialist music teaching) in a common enterprise of building the generalist teacher's skills in music teaching. This approach provided opportunity for learning by both mentor and mentee in a process of collaborative self-development (Kemmis et al., 2014) in which individual strengths were recognised. As one mentee noted: My mentor respected that I was a teacher and that I knew my children (Mentee, School 5). The mutually beneficial nature of a collaborative self-development approach and the long-term benefits beyond the life of the mentoring program are evident below:

We emphasized the fact that there was an expectation in the program that we [mentors] would all learn from it as well, that we would all grow, that it's not just about us imparting something to others, that there's a professional development involved for us as well. I certainly learnt things from the teachers that I worked with. (Mentor 3)

The quality of mentoring relationships has been excellent. The mentor and teachers obviously had a really good rapport and it's been mutually beneficial (Principal, School 4)

Because my relationship with the teachers being mentored had become so rich, so fruitful, and so wonderful with the students as well, that I know that I will be in touch with them forever. (Mentor 4)

\section{Theme 2: Identification and realisation of individual and collective goals for music teaching}

All groups of participants were able to identify goals for themselves and their classes. These included the desire to build confidence in using music in the classroom.

I've been interested in how we can bring music back into the classroom, in everyday situations and little time-fillers, and also just to develop my own confidence in being able to do that. (Mentee, School 11) 
They've found that the professional learning was easily translated into what they're doing in the classroom, very practical and helped them to feel more confident about what they're doing with music in their classrooms. (Principal, School 7)

Hargreaves and Fullan (2012) note that a sharing rather than defensive approach to failure and uncertainty is more productive in mentoring relationships. A key element in building confidence was an open and honest assessment of commencing skills and knowledge and a recognition by the mentors of the degree to which their colleagues were vulnerable in the process as evidenced below:

Teachers brought an open willingness to talk about their inadequacies in the area of music and disappointment that this hadn't been addressed in a more thorough way at university (Mentor 4)

Particularly one or two of the teachers I mentored, their nerves were quite high about music even though in terms of teaching I admire them greatly for the work they do. I had to be very, very positive. (Mentor 6)

Mentees' personal goals included developing the skills to use music as a transition activity, to sing with their children, and to integrate technology,

One teacher wanted brain breaks or transition type activities, and that's what we hooked into and that's what I provided for her. (Mentor 6)

My goal was to be able to sing confidently with my children and to be able to read notes. The mentor would start each lesson focussing on what my goal was and then introduce some new things. (Mentee, School 10)

My goal was to integrate technology more into the program and to use percussion instruments, and also to devise a plan that could be user-friendly and used by other staff members. (Mentee, School 4)

Mentees noted the program aspects that facilitated the identification and achievement of their goals including working with an experienced mentor, joint planning, and clear foci for each lesson.

I think the program that we were given by the mentor was really helpful for someone that didn't know where to start. (Mentee, School 6) a

We planned all the activities, they had so many resources and the program that we did it was very extensive. (Mentee, School 4)

Each lesson focussed on a different musical concept, whether it's pitch or beat or rhythm or musical notation, how to be a composer or a conductor, how to use terminology and understand it completely. (Mentee, School 2)

\section{Theme 3: Reflection, feedback and joint planning informing learning}

The program provided opportunity for extensive reflection and feedback offered through face-toface meetings, written commentary by mentors on planning documents, and feedback by mentors 
on observations. Mentees were alert to the opportunities that reflection and feedback provided noting that:

The mentor observed us on a number of occasions and videoed us on a number of occasions. The videoing was quite confronting but very informative (Mentee, School 1).

The mentor videoed us so that she could give us feedback about what she observed and we could watch ourselves back as well. (Mentee, School 10)

When you have an expert watching you try and deliver something that's in their field, it's always good to hear what they have to say (Mentee, School 2)

My mentor was really enthusiastic and really understanding and always made it known that she was available whenever we needed help. (Mentee, School 6)

Having that feedback session was so important, sitting one-to-one, because if it was a group scenario I don't feel I would have got much out of it. (Mentee, School 10).

By the second or third lesson, I was feeling a lot more comfortable and thinking more about what I was looking for in children in terms of learning intention and whether that was successful. (Mentee, School 10)

The reflection was my favourite part, it was really important to me. In the reflection I was working out where to next, what could I extend more in the next lesson. (Mentee, School 11)

Both mentors and mentees commented on the importance of joint planning in building knowledge and skills, including in identifying resources such as YouTube clips (including self-developed clips) and aural models of repertoire on USB.

I've supplied resources that I have from my own teaching practice: rhythmic syllables, flash cards, picture cues, all sorts of song game resources. I offered the materials and the teachers had made use of them (Mentor 5).

Giving teachers suitable repertoire or finding appropriate quality YouTube clips for them to use to deliver what they wanted and trying to educate them in terms of musical elements and content. (Mentor 2)

The mentor created videos of her doing the songs and put them up on YouTube. That was a really good resource, it was engaging for children to see her on the screen and see the song being performed. (Mentee, School 6)

I just keep adding to that USB and this helped them to keep going and get over the fear of singing. (Mentor 6)

I ended up coming to school one day and just recording my voice singing the songs so that the teacher had a cue to help her learn them. (Mentor 5)

The mentor made a PPT where she had put the lyrics of over 80 songs and recorded herself singing each song. (Mentee, School 10) 


\section{Theme 4: Integration of music into daily activities, lesson transitions, school culture}

The greater use and integration of music in the mentee's classrooms was evident in many interviewee responses. Not only were participants more confident and skilled in implementing music into their daily practice, they reported being more knowledgeable of the benefits of such activities for the children with whom they work:

Now teachers see there's an actual benefit in music, even if it's only for a five-minute gap between lessons or giving children a break between their sessions to do something totally different and then come back to whatever work they plan to do. (Mentor 5)

Singing is a wonderful resource, because all of a sudden instead of calling everyone's attention, you could either do a rhythm or you could sing "Are you ready?" and then all of a sudden, the whole class turns around and sings, "Yes, we are." Pens down, they're on the mat. (Mentor 4)

When I mark the roll, I sing a variety of melodies to the children. They've become incredibly good at mimicking that back, they all sing it back. It's not a music lesson, we're just marking the roll, but it's a musical roll. (Mentee, School 1)

I use music for transitions and in mathematics when we're warming up, like counting songs. (Mentee, School 5)

\section{Theme 5: Creating a community of music practice in and across schools}

The mentoring approach of collaborative self-development facilitated the development of a community of music practice both within the mentee participants' schools and across those schools in which the mentors worked. Sharing and collaboration, networking, peer-to-peer and collegiate support were reported as outcomes:

The teachers were seeking out materials and resources in-between the mentoring sessions. This sharing and collaboration around appropriateness of musical learning tasks for the students was really pleasing to see (Principal, School 11)

The best support was networking with the other mentors and getting ideas from each other. Having that peer-to-peer support from people doing the same thing as you was good. (Mentor 3)

We'd often have a lesson plan but it would never go as planned, because each of us would think of something either musically important to say or we'd think of another song with another game which would embellish what we had just been doing. It was collegiate support and we were doing it for the best educational outcomes. (Mentor 5)

\section{Theme 6: Improved classroom climate and enhanced student engagement and positive behaviours}

Significant amongst the outcomes of the program for participants were those for children. Mentor, mentee, and principal participants reported the ways in which the introduction of music into the daily program had positive impact not only on the children's musical development (Barrett et al., 
2018), but also on the classroom environment, children's enjoyment of their school day, enhanced engagement and positive behaviours:

Direct feedback from the teachers that have been mentored about how wonderful it's been, how it's made a difference to their class, the climate in their classroom. (Principal, School 10)

The mentee has got a pretty difficult class, with an eclectic range of children. I think the mentoring program has been able to contribute to other things such as classroom management because of some strategies and cues that she uses now, and getting the children to engage and to stay longer on-task. (Principal, School 7)

What I saw in the children was, first of all confidence; second, joy, as soon as there was music, they were all way hanging out for it, so they were always excited. (Mentor 1)

Just seeing the joy on children's faces when I turned up every week, they just loved singing and everything we did. (Mentor 3)

The teacher was absolutely speechless about this little boy who had a number of learning difficulties, would not speak, incredibly poor self-esteem. But he got up and sung and had confidence, and we gave him a big music award that day. (Mentor 2).

I've been singing the instruction and students have been more inclined to listen to the whole set of instructions, it's really engaged them a lot more. (Mentee, School 11).

One week in assembly I asked the children to stand up and sing one of the songs that I heard them sing, and they stood up after only a few weeks of mentoring and sang to the whole assembly. It felt really wonderful and the parents clapped and applauded. (Principal, School 5)

Some of the children that made the most progress were the ones that had absolutely no musical sense at all, no musical knowledge and no confidence. (Mentee, School 4)

Children learnt how to listen to their voices and make sure that they're starting on the right pitch and using hand movements to mimic where their voices are going. (Mentee, School 5)

In discussing learning outcomes for children, the role of music in promoting learning and engagement for children with ESL was notable.

Thirty percent of our students come to us with no English at all, and now they're learning chunks of language because of singing. Songs make a huge difference to children learning English, because otherwise they're just silent (Mentee, School 1)

We have a lot of ESL children here and it's been delightful to see students who might not be so confident in reading and writing to love music so much and be good at it. (Mentee, School 5)

Children who have not had a lot of success in literacy and numeracy were having amazing success in music. Music can change the whole landscape of a child's life. (Mentor, 4). 


\section{Research question two: What are the qualities of effective music mentoring?}

\section{Theme 7: Building teacher confidence and competence for music leadership}

The literature on effective mentoring emphasises the importance of reflection, experimentation, and autonomous decision-making (Richter, 2013), open and honest self-appraisal (Hargreaves and Fullan, 2012), and a conversation that arises from documentation and practical tasks (Sundli, 2007). Such approaches aim to build confidence and competence as evidenced below:

Teacher confidence to sing, even though their voices might not be great, was much more evident after mentoring because they had strategies, ideas and a repertoire of things that they could do. (Principal, School 10)

I'm feeling a lot more confident to try out some different things, for example I can take a literacy task and turn it into a music activity. (Mentee, School 7)

The program was uplifting. It's something that I hadn't anticipated with that emotional synergy that would flow from it. Those teachers looked to be having a lot of fun when everyone else was being a bit stressed. (Principal, School 11)

There's no way I can give teachers all the music experience and knowledge that I have in [x] number of mentoring sessions. What I can do, is give them some techniques which will help them in their music teaching, empowering them to be able to find things for themselves. (Mentor 3)

The development of music leadership for both mentors and mentees was noted as an outcome of the increased competence and confidence enabling a cascade effect of music mentoring in a number of schools subsequent to the program implementation:

Given the opportunity to mentor others, [the mentor] has been very confident about her leadership skills. She's proud of what she does by showing other people her skills and her knowledge (Principal, School 10)

Mentoring is a huge job and it really should be recognised as a demonstration of leadership within your subject, a leadership of people and children. (Mentor 3).

At the end of mentoring we decided as a $K-2$ we were going to write the lessons and create a program to run in the whole school. (Mentee, School 4)

We need mentoring to say, "Well, actually you can do this in your classroom". Music doesn't just happen for an hour a week, it can happen through the day, every day. It's just having a mindset that we can do this. (Mentee, School 10).

I know their confidence has really grown, and the mentor has given them a range of strategies from just the very low-level right through to ways they can incorporate music in their day-today teaching, and how they can do lessons that they'd probably never considered before, ways of teaching that they'd never considered before. (Principal, School 2) 


\section{Theme 8: Observation of expert practice as a learning tool}

Observation of expert practice was a feature of the workplace mentoring model. These observations occurred in a range of ways, including mentees visiting mentors' workplaces in order to observe them teaching in their own setting, observing mentors teaching 'model lessons' with the mentees' class, and, in turn, mentees being observed by mentors. Participants commented on the benefits of such experiences:

For me, watching my mentor was probably the most valuable thing. I've never seen a really good music lesson live (Mentee, School 6)

We went to observe the mentor in her school and then she did demonstration lesson with my class (Mentee, School 4)

Seeing how the mentor structured a lesson and being able to sit back and take notes helped me model how I was going to teach a lesson. (Mentee, School 11)

You talk to those who do it, you watch them and you learn from them, because a list of resources is a dead thing unless it's alive in your mind. Until you actually teach something, it's not part of you. (Mentor 7)

[The mentor was] observing while I'm teaching and giving feedback, also modelling lessons. And also just assisting in the classroom when there's a lesson, so we're sort of team-teaching. (Mentee, School 6)

The mentor would come in and just sit there and observe and join in where possible. Then at the end we'd do a bit of reflection and a quick chat about what worked and what didn't work. It was a really important to go through this process. (Mentee, School 10)

\section{Theme 9: Focused feedback, planning and implementation of lessons}

Focused feedback has been identified as the single most important factor in learning (Hattie and Clarke, 2019). Mentor and mentee participants spoke at length on how to provide feedback, the nature of feedback, and the function of feedback.

You don't have to be negative about things, you'd say "That was really great how that worked" and together we would end up saying, "Okay, let's alter that, but maybe let's do it in this order next time or maybe let's not choose that particular version, let's go for this version". (Mentor 2)

My mentor was very enthusiastic and inspirations, very good at giving everyone positive feedback, whether it's me or the students. (Mentee, School 8)

Always positive reinforcement and constructive criticism, [my mentor] didn't actually put me down. (Mentee, School 10) 
Theme 10: Continuous specialised, collaborative workplace mentoring, instead of one-off professional development (PD)

Conway has highlighted the importance of focused specialist mentoring (2015) that is undertaken in the real-world settings of the participants' workplace. A key feature of the mentoring program approach was its longitudinal nature, workplace focus and collaborative self-development orientation. This approach was commented on as a key element of successful mentoring as evidenced below:

I think being mentored by somebody you're connected to, who you can build a relationship with, who knows the school well and can tweak the way they mentor you based on the way your school works, is much more powerful than visiting somewhere else or going to an external PD and trying to capture it in one day and then come back and try and implement it without any feedback. (Principal, School 10)

This program offers professional learning that is real and meaningful because it's actually in the classroom, it's happening with the children, it's part of their normal workload and for me that professional learning is one of the most important things. (Principal, School 9)

Having someone who is showing them, teaching them, working with them over an extended period of time is the best way to learn anything. (Principal, School 5)

Initially at the start of the year the teaching was more directed by the team leader, whereas now the mentee is taking the lead and has confidence to be able to share and to utilise the expertise she's gained. (Principal, School 4)

It was a lot of team-teaching. Towards the end I led more and then it all (Mentee, School 8).

We did a lot of collaborative planning and the mentor brought suitcases full of resources to the school to share with us. If we didn't feel confident about doing some part, she would help with that and let us go with the rest of it. (Mentee, School 4)

We would talk at the end of each week about what we do the following week, and I would say, "Look, I demonstrated that little activity this week, how about you try that next week and then I'll introduce something new". Half way through the program the teacher said to me, "Can I go first? Can I do my thing first?" She had a whiteboard with ta and ti-ti flashcards and instruments ready. This was a tipping point into confidence. (Mentor 3)

\section{Research question three: What are the qualities of an effective music mentor?}

Theme 11: Sensitivity, responsiveness, situational awareness, flexibility, and subject and pedagogic expertise

The literature suggests that the capacity for empathy, collegiality, sharing of information, and positive relationships characterises the work of an effective mentor (Ehrich et al., 2004; Langdon et al., 2016). These qualities were evident in the responses of mentors, mentees and principals when asked what makes a good mentor: 
A good mentor is someone who comes in and just supports you quietly and confidently and they know what their goal is for me and then they can help me achieve my goals. I know that they're not coming in with a critical eye but they're coming in to help me, to mentor me, to help me to improve my skills. (Mentee, School 10)

I think a good mentor is someone who can impart a confidence in the person they're mentoring, like a self-belief, so they realise they can do something they didn't think was possible. And someone that can bring out the best qualities of the person they're mentoring without being too confrontational or didactic, just by working alongside but still demonstrating the best qualities. (Mentor 3)

Mentoring provided an opportunity for them to think about curriculum and their practice in a way that's been quite uplifting, because music does de-stress and creates some joy and fun and connectedness with children and with each other. That's probably something that I hadn't anticipated - that emotional synergy that would flow from it. Those teachers looked to be having a lot of fun when everyone else was being a bit stressed. (Principal, School 11)

Importantly, mentors were situationally aware because of the development of a longer-term relationship in the program design and able to provide site-specific advice, planning and resources that supported teachers in their daily practice:

The mentor brought many resources and also went into our library and explained how our own resources were valuable and how we could use them. (Mentee, School 4).

I gave teachers a very extensive resource list, with links to websites as to where as to where you can source them from, also links to website and apps, percussion catalogues so that they can purchase more instruments for the school. (Mentor 3)

Participants also commented on the importance of flexibility and openness to change, particularly when undertaking difficult conversations:

The mentor was very accommodating and flexible, if we had to change things according to school activities, she was happy to step in and support me. (Mentee, School 4)

An effective mentor is someone who is going to encourage you and give you some advice, then give you a chance to use that advice and reflect on it. (Mentee, School 7)

I repeat the same lesson to five classes in the same grade. When I do things that don't work in one lesson, I can repeat and improve it. You often teach better when you repeat it. (Mentor 1)

We were totally prepared with our lesson plans and, of course, we changed things along the way. (Mentor 2)

[The mentoring process meant] having good quality conversations with people, sometimes difficult conversations that needed to cover a lot in the minimum amount of time (Mentor 7).

Implicit within the notion of a mentor who is a specialist is an assumption that the individual brings deeper and broader music and music pedagogy knowledge, including managing music learning in 
particular environments, and related to the organisational and people skills necessary to facilitate learning by all participants (Conway \& Hodgman, 2006; Smith, 2005). These qualities were evidenced in a number of responses:

I think a mentor definitely needs to know their content, and, if they don't know, be able to direct you where to find some handy hits or knowledge on that particular part of the curriculum. (Mentee, School 11)

Good mentors need to be wonderful music practitioners, well organised and have confidence and belief in themselves to walk into other schools and be able to mentor. (Mentor 3)

I was able to show teachers how to sequence through a lesson: a warm up activity, always developing some fundamental skills, how to teach a song. (Mentor 1)

[The mentor] was very good at assessing children, noticing "Okay, this is as far as we can take the children today, we need to just reinforce what we're doing before we move forward" (Principal, School 9)

[The mentor] told me how children had to stand and how to keep that focus in their minds. (Mentee, School 4)

[The mentor] was aware that my class was very different from X's class and she talked about a range of strategies that would be suitable for different ages and abilities. (Mentee, School 7)

Organisation skills (time management, resources, behaviour management)

The mentor came to us and gave us lots of resources to look at prior to the lessons, and then we typed up our own lessons and formulated our own lesson plans. (Mentee, School 10)

The mentor's knowledge of curriculum and sequencing of concepts really came to the forefront. (Mentee, School 11)

People skills (warm, approachable, gentle, non-judgemental, positive, passionate)

The key thing in the mentoring process is that to establish a good relationship and a trusting relationship. (Mentor 1)

A mentor needs to obviously have good interpersonal skills, because it's hard to work with someone if you don't have a good relationship, so it's always good to have good interpersonal skills. (Mentee, School 11)

Being a good listener, being really flexible, being able to understand the person that you're mentoring quite quickly, being able to read their mood, being able to put them first. It's not about the mentor. (Mentor 4) 


\section{Discussion}

This study focused on evaluating the impact of workplace mentoring of early childhood classroom teachers by music specialists to enhance their music-teaching skills. The approach implemented in this mentoring program demonstrates some of the elements of Jacobs' (2008) pyramid model in that it began with the funding from the Federal Government, was designed and supported by a professional music organisation (name withheld for review), selected and trained mentors, and provided mentor and mentee release time. In addition, a "cascade" or "ripple" effect, i.e., the ability of mentored teachers to mentor others in their schools, was observed here. Similar approaches to peer-group mentoring of Primary teachers in Finland have resulted in sustainable school development (Johnson and Alamaa 2012).

\section{Outcomes for mentors, teachers and students}

Mentors built positive relationships with their mentees based on mutual respect, with mentors reporting additional benefits of learning from each other and from the mentees. Building collaborative collegial relationships was a form of "collaborative self-development" (Kemmis et al. 2014).

Mentees emphasised their lack of confidence in teaching music prior to the mentoring program. This attitude has been flagged by research and has shown that generalist teachers' experience of the arts during their training "tended to be marginalised both in terms of time and priority" (Kenny, Finneran, and Mitchell 2015, 164). Participants identified how the program had helped them to develop relevant lesson structures, resources and teaching strategies. This finding is supported in the literature that suggests that mentoring should assist in building practical skills (Orland-Barak 2014; Sundli 2007).

As expected, the program had developed teachers' music-teaching skills and resulted in growth in their confidence in music teaching. This finding aligns with the results of the evaluation of the UK Sing up program (Himonides et al. 2011). Similarly, Swain and Bodkin-Allen (2017) showed that "gaining some knowledge of singing techniques [leads] to a sense of empowerment" in early childhood teachers (109). Research has shown that music mentoring by music specialists helps teachers acquire discipline-specific knowledge and teaching strategies (Draves and Koops 2011; Schmidt 2008) and builds their confidence (Davis 2016; Lamont et al. 2012).

The most immediate focus of mentoring for both mentors and mentees was on enhancing children's learning as previously flagged by research (Langdon et al. 2016). The findings highlight the positive impact of mentoring on music learning outcomes for children and other academic outcomes (Barrett et al. 2018; Martinez 2004; Saunders et al. 2014).

The mentoring program had a positive effect on staff morale and classroom dynamics. This finding aligns with literature predictions that effective mentoring can invigorate teachers and lead to greater job satisfaction (Martinez 2004; Richter et al. 2013). Similarly, a recent review of 17 case studies of music provision in Australian schools by Lee, Krause and Davidson $(2017,73)$ 
demonstrated that effective music programs in schools "improve psychosocial well-being of the students and the community".

\section{Qualities of effective music mentoring}

Breaking down the fear of singing, creating singing resources and integrating singing into everyday school activities were the main goals of mentoring in this study, addressing a lack of singing skills among generalist classroom teachers that has been noted in previous research (Lamont et al. 2012). Research suggests that practical art activities are essential for building teacher confidence in teaching in art areas (Kenny et al. 2015) and mentees engagement in practical experience was identified as a key aspect of mentoring.

Mentors modelled effective music teaching practice and observed developing practice of their mentees, refining the effectiveness of their teaching strategies. Langdon and Ward (2015) proposed such a "knowledge-in-practice" approach for mentoring, helping teachers gain practical knowledge through hands-on experience.

When working with mentees, a flexible approach and positive feedback were important in building teacher confidence. Research has demonstrated that mentoring approaches that include collaborative inquiry and critical reflection are beneficial (Richter et al. 2013). The importance of a constructive mentor-mentee relationship has been documented (Haggard et al. 2011; Langdon et al. 2016) and was in evidence here, as seen in comments concerning practical approaches to mentoring, a shared passion for music and teaching, and praise for achievements. Enhanced mentees' confidence to teach music enabled them to share their new knowledge with colleagues. This contrasts with mentoring approaches that tend to focus on "getting the job done rather than building self-efficacy" (Rhodes and Fletcher 2013, 58).

\section{Qualities of effective music mentor}

The qualities of an effective music mentor include both music specific aspects such as strong subject knowledge, excellent musicianship, and a compatible music philosophy with more generalised qualities such as being a good listener, being organised, being personable and professional (Conway and Hodgman, 2006). Findings identify that mentors' passion for music, their expert knowledge and skills, and their mission to transform generalist classroom teachers' attitudes towards music were key qualities in their professional work. The capacity to observe and analyse mentee's music practice and provide targeted feedback in a nurturing and affirming manner (Smith, 2005) was also identified as a key quality in these music mentors' work, as were exemplary organization, empathy, collegiality, sharing of information and positive relationships (Ehrich et al., 2004; Langdon et al., 2016).

\section{Conclusions and implications}

As mentioned in the article opening, an eminent Australian music educator [Dr Richard Gill AM] sought to address a commonly reported need amongst generalist Primary school teachers concerning their lack of confidence in the teaching of music in general and singing in particular. 
This need has been widely reported in research studies over many years, such as by Mills (1989), Hennessy (2000), Stunell (2006) and McCulloough (2006) in England, Stakelum (2008) in Ireland, Ballantyne (2007), Barton (2015) and Jeanneret (1997) in Australia, Bresler (1993) in the USA, and also in non-English speaking countries, such as Austria, Italy, Netherlands and Slovenia (Biassutti et al 2015), Portugal (Mota 2015), and Brazil (Mateiro 2011). Separately, it has been reported that one of the main underlying reasons for this persistent need is that generalist initial teacher education programs customarily provide limited opportunities for sustained pre-service education in music (e.g., Erhlin \& Wallerstedt 2014; Gifford 1993; Hennessy 2017; Koutsoupidou 2010; Welch \& Henley, 2014).

Possible solutions include on-the-job mentoring, which is seen as an effective means of enhancing skills, knowledge and understanding in an ecologically valid way. Such an approach has resonance with the findings from the recent British Educational Research Association's review of how closeto-practice research can bridge the gaps between research, policy and practice by involving practitioners collaboratively in the research endeavour (BERA, 2018). Successful workplace examples have been reported within diverse employment settings, such as with nurses, engineers and chartered accountant ( $c f$ Bierema \& Eraut 2004; Eraut 2004; Eraut 2007; Eraut et al, 1998), as well as in higher education teaching and learning in biological sciences, economics and electronic engineering (Entwistle, 2005; Hounsell et al 2005). This Australian program of music mentoring, [NMTMP], is aimed to develop practising generalist early childhood ( $\mathrm{K}-$ Year 2, ages 5-8y) teachers' knowledge and skills in music education and their capacity to lead music education experiences in their classroom. In its first iteration (2015), the program paired specialist music teachers with generalist classroom teachers in negotiated mentoring relationships.

Overall, our findings (as reported above) endorse the general principle of mentoring and its school-focused enactment, in that this program drew on both "support" and "collaborative selfdevelopment" models of mentoring (Kemmis et al. 2014). The program "supported" mentees in building self-belief, confidence and competence in music teaching. Additionally, as mentees and mentors were experienced practitioners in complementary domains (music and early childhood education respectively), they were able to undertake collaborative professional discussions as equals, providing opportunities for professional growth for all parties (cf Kram 1985; Eraut 2011). Participants evaluated the program as building teachers' confidence in leading music learning activities and using music in their classroom, and in developing their competence to design and implement effective learning in music. Such positive perceptions were supported by a separate strand of the research evaluation which found that children in the participating classes made significantly greater gains in their singing competency compared to peers in non-mentored control classes (Barrett et al, 2018). The model of workplace mentoring over an extended period also contributed to building mentees confidence to disseminate their newly developed knowledge and skills with colleague teachers. Successful mentoring in the program rested in the mentors' passion for music and commitment to effecting positive change in the lives and learning of mentees and the children with whom they worked. The mentors' capacity to build positive and respectful relationships and be situationally responsive and flexible in addressing individuals' needs was also key to successful outcomes. It should be noted that all participants in the program (mentees and 
mentors) were volunteers, indicating an interest in the focus of the professional learning (music) and a commitment to the longitudinal collaborative model of working with a professional peer. Further, the school Principals were supportive of the program and accommodated the necessary teacher release and allocation of resources within the whole-of-school planning. We suggest that these elements, whilst not stated explicitly, also contributed to the success of the program.

The findings clearly evidence the success of this model of workplace music mentoring in building early childhood generalist teachers' capacity to include music in their programs. We recommend that consideration be given to embedding a similar model of long-term workplace music mentoring as "collaborative self-development" across all years of Primary teaching.

Acknowledgement of Funding: This research was supported by funding administered through the Australian Youth Orchestra.

\section{References}

ABS (Australian Bureau of Statistics). 2016. 2071.0 "Census of Population and Housing: Reflecting Australia - Stories from the Census, 2016". Retrieved from http://www.abs.gov.au/ausstats/

Ballantyne, J. 2007. "Documenting praxis shock in early-career Australian music teachers: The impact of pre-service teacher education." International Journal of Music Education, 25 3: 181 191.

Barrett, M.S., Zhukov, K., Brown, J.E. \& Welch G.F. (2018). Evaluating the impact of a generalist teacher-led music program on early childhood school children's singing skills and attitudes to music. Psychology of Music, published 16.08.2018 First On-Line.

Barton, G. 2015. "Developing confidence and competence as a pre-service music teacher: personal epistemology in a middle years course." Australian Journal of Music Education, 3: 16-25.

Benson, M. A. 2008. "Effective Mentoring for New Music Teachers: An Analysis of the Mentoring Programs for New Music Teachers as Described in the Literature." Update: Applications of Research in Music Education 26 (2): 42-49.

Berg, M. H., and C. Conway. 2016. "The Design and Implementation of the ASTA Mentor Program: Perceptions of Program Developers and Mentor Preparation Workshop Participants." String Research Journal 7: 63-81.

Berg, M. H., and D. A. Rickels. 2018. "Mentoring for Mentors: The Music Mentor Plus Program." Journal of Music Teacher Education 27 (2): 39-51.

Biasutti, M., Hennessy, S., and de Vugt-Jansen, E. 2015. "Confidence development in non-music specialist trainee primary teachers after an intensive programme." British Journal of Music Education 32 (2), 143-161.

Bierema, L., and Eraut, M. 2004. "Workplace-Focused Learning: Perspective on Continuing Professional Education and Human Resource Development." Advances in Developing Human Resources, 6 (1), 52-68.

Blair, D. V. 2008. "Mentoring Novice Teachers: Developing a Community of Practice." Research Studies in Music Education 30 (2): 97-115. 
Braun, V., and V. Clarke. 2006. "Using Thematic Analysis in Psychology." Qualitative Research in Psychology 3 (2): 77-101.

Bresler, L. 1993. "Music in a Double-Bind: Instruction by Non-Specialists in Elementary Schools." Bulletin of the Council for Research in Music Education, 115, 1-13.

Collins, A. M. 2016. "Generalist Pre-Service Teacher Education, Self-Efficacy and Arts Education: An Impossible Expectation?" International Journal of Education and the Arts 17 (26).

http://www.ijea.org/v17n26/v17n26.pdf

Conway, C. 2008. "Perceptions of Experienced Music Teachers Regarding Their Work as Music Mentors." Journal of Research in Music Education 56 (1): 55-67.

Conway, C. 2015. "Beginning Music Teacher Mentor Practices: Reflections on the Past and Suggestions for the Future." Journal of Music Teacher Education 24 (2): 88-102.

Conway, C. M., and T. M. Hodgman. 2006. "Mentoring." In Handbook for the Beginning Music Teacher, edited by C. M. Conway and T. M. Hodgman, 201-209. Chicago: GIA Publications.

Costantoura, P. 2000. Australians and the Arts: What Do the Arts Mean to Australians? Sydney: The Australia Council for the Arts.

Creswell, J. W. 2015. A Concise Introduction to Mixed Methods Research. Los Angeles, NJ: SAGE.

Davis, S. A. 2017. "A Circular Council of People with Equal Ideas: The Mentoring Mosaic in Preservice Teacher Education Program." Journal of Music Teacher Education 26 (2): 25 - 38. doi: $10.1177 / 1057083716631387$

DEST (Department of Education, Science and Training). 2005. National Review of School Music Education: Augmenting the Diminished. Canberra, Australia: Australian Government.

Devos, A. 2010. "New Teachers, Mentoring and the Discursive Formation of Professional Identity." Teaching and Teacher Education 26: 1219-1223.

Draves, T. J., and L. H. Koops. 2011. "Peer Mentoring: Key to New Music Teacher Educator Success." Journal of Music Teacher Education 20 (2): 67-77.

Ehrich, L. C., B. Hansford, and L. Tennent. 2004. "Formal Mentoring Programs in Education and Other Professions: A review of Literature." Educational Administration Quarterly 40 (4): 518540.

Entwistle, N. 2005. "Learning outcomes and ways of thinking across contrasting disciplines and settings in higher education." Curriculum Journal, 16:1, 67-82, DOI:

10.1080/0958517042000336818

Eraut, M. 2007. "Learning from other people in the workplace." Oxford Review of Education, 33:4, 403-422, DOI: 10.1080/03054980701425706

Eraut, M. 2011. "Informal Learning in the Workplace: Evidence on the Real Value of Work-Based Learning (WBL)." Development and Learning in Organizations 25 (5): 8-12.

Eraut, M., Alderton, J., Cole, G., and Senker, P. 1998. "Learning from other people at work." In Learning at work, edited by F. Coffeld, 37-48. Bristol: Policy Press.

Erhlin, A., and Wallerstedt, C. 2014. "Preschool teachers' skills in teaching music: two steps forward one step back." Early Child Development and Care, 184(12), 1800-1811.

Gifford, E. 1993. "Why is pre-service training in music for general primary teachers so unsuccessful?" Queensland Researcher, 9(3), 28-35.

Given, L. M., and K. Saumure. 2008. "Trustworthiness." In The SAGE Encyclopedia of Qualitative Research Methods, edited by L. M. Given, 896-987. Thousand Oaks: SAGE. 
Haggard, D. L., T. W. Dougherty, D. B. Turban, and J. E. Wilbanks. 2011. "Who is a Mentor? A Review of Evolving Definitions and Implications for Research." Journal of Management 37 (1): 280-304.

Hamel, F. L., and H. A. Jaasko-Fisher. 2011. "Hidden Labor in the Mentoring of Pre-Service Teachers: Notes from a Mentor Teacher Advisory Board." Teaching and Teacher Education 27: 434-442.

Hargreaves, A., and M. Fullan. 2012. Professional Capital: Transforming Teaching in Every School. London: Routledge.

Hattie, J. \& Clarke, S. (2019). Visible Learning Feedback. Abingdon, Oxon: Routledge.

Hennessy, S. 2000. "Overcoming the Red-Feeling: The Development of Confidence to Teach Music in Primary School amongst Student Teachers." British Journal of Music Education 17 (2): 18396.

Hennessy, S. 2012. "Improving Primary Teaching: Minding the Gap." In Oxford Handbook of Music Education, edited by G. E. McPherson and G. F. Welch, 625-628. New York: OUP.

Hennessy, S. 2017. "Approaches to increasing the competence and confidence of student teachers to teach music in primary schools." Education 3-13, 45:6, 689-700, DOI:

10.1080/03004279.2017.1347130

Himonides, E., Saunders, J., Papageorgi, I., \& Welch, G. (2011). Researching Sing Up's Workforce

Development. London: International Music Education Research Centre, Institute of Education. Hocking, R. 2009. "National Audit of Music Discipline and Music Education Mandatory Content Within Pre-Service Generalist Primary Teacher Education Courses." Canberra: Music Council Australia. Retrieved 1 October 2018.

http://musicinaustralia.org.au/images/9/9b/Hocking preservice 2009.pdf

Hounsell, D., and Entwistle, N., with Anderson, C., Bromage, A., Day,K., Hounsell, J., Land, R., Litjens, J., McCune, V., Meyer, E., Reimann, R., and Xu R. 2005. Enhancing teaching-learning environments in undergraduate courses. Final Report to the Economic and Social Research Council on TLRP Project L139251099.

Jacobs, J. N. 2008. "Constructing a Model for the Effective Mentoring of Music Educators." Journal of Music Teacher Education 17 (2): 60-68.

Jeanneret, N. 1997. "Model for Developing Preservice Primary Teachers' Confidence to Teach Music." Bulletin of the Council for Research in Music Education, 133, 37-44.

Johnson, P., and S. Alamaa. 2012. "Mentoring as Sustainable School Development." In Peer-Group Mentoring for Teacher Development, edited by H. L. T. Heikkinen, H. Jokinen and P. Tynjälä, 5259. London: Routledge.

Kemmis, S., H. L. T. Heikkinen, G. Fransson, J. Aspfors, and C. Edwards-Groves. 2014. "Mentoring of New Teachers as a Contested Practice: Supervision, Support and Collaborative Self-

Development." Teaching and Teacher Education 43: 154-164.

Kenny, A., M. Finneran, and E. Mitchell. 2015. "Becoming an Educator in and through the Arts:

Forming and Informing Emerging Teachers' Professional Identity." Teaching and Teacher Education 49: 159-167.

Kerin, M, and C. Murphy. 2015. "Exploring the impact of Coteaching on Pre-Service Music Teachers." Asia-Pacific Journal of Teacher Education 43(4): 309-323. 
Koutsoupidou, T. 2010. "Initial Music Training of Generalist Kindergarten Teachers in Greece: What Do They Ask For and What Do They Receive?" Arts Education Policy Review, 111:2, 63-70, DOI: 10.1080/10632910903455892

Kram, K. E. 1985. Mentoring at Work: Developmental Relationships at Work. Glenview, IL: Scoot, Foresman and Company.

Lamont, A., A. Daubney, and G. Spruce. 2012. "Singing in Primary School: Case Studies of Good Practice in Whole Class Vocal Tuition." British Journal of Music Education 29 (2): 251-268.

Langdon, F. J., P. A. Alexander, S. Farquhar, M. Tesar, M. G. R. Courtney, and M. Palmer. 2016. "Induction and Mentoring in Early Childhood Educational Organizations: Embracing the Complexity of Teacher Learning in Contexts." Teaching and Teacher Education 57: 150-160. Langdon, F., and L. Ward. 2015. "Educative Mentoring: A Way Forward." International Journal of Mentoring and Coaching in Education 4 (4): 240-254.

Lave, J. and E. Wenger. 1991. Situated Learning: Legitimate Peripheral Participation. Cambridge: Cambridge University Press.

Lee, J., A. E. Krause, and J. W. Davidson. 2017. "The PERMA Well-Being Model and Music Facilitation Practice: Preliminary Documentation for Well-Being through Music Provision in Australian Schools." Research Studies in Music Education 39 (1): 73-89.

Lincoln, Y. S. 2004. "Trustworthiness criteria." In The SAGE Encyclopedia of Social Science Research Methods, edited by M. S, Lewis-Beck, A. Bryman and T. F. Liao, 1145-1146. Thousand Oaks: SAGE.

Martinez, K. 2004. "Mentoring New Teachers: Promise and Problems in Times of Teacher Shortage." Australian Journal of Education 48 (1): 95-108.

Mateiro, T. 2011. "Preparing Music Teachers in Brazil." In Educating Music Teachers for the $21^{\text {st }}$ Century, Edited by J. L. Aróstegui, 147-174. Rotterdam: Sense Publishers.

MCEECDYA (Ministerial Council for Education, Early Childhood Development, and Youth Affairs). 1989. The Hobart Declaration on Schooling in the $21^{\text {st }}$ Century. Canberra, Australia: Australian Government. Retrieved from: http://www.educationcouncil.edu.au/EC-Publications/ECPublications-archive/EC-The-Hobart-Declaration-on-Schooling-1989.aspx

MCEECDYA (Ministerial Council for Education, Early Childhood Development, and Youth Affairs). 1999. The Adelaide Declaration on National Goals for Schooling in the $21^{\text {st }}$ Century. Canberra: Australian Government. Retrieved from:

http://www.scseec.edu.au/archive/Publications/Publications-archive/The-AdelaideDeclaration.aspx

MCETYA (Ministerial Council for Education, Training and Youth Affairs. 2007. National Statement on Education and the Arts. Canberra: Department of Communication, Information Technology and the Arts.

MCETYA (Ministerial Council for Education, Training and Youth Affairs). 2008. Melbourne Declaration on Education Goals for Young Australians. Retrieved from:

http://www.educationcouncil.edu.au/site/DefaultSite/filesystem/documents/Reports\%20and\% 20publications/Publications/National\%20goals\%20for\%20schooling/National Declaration on $t$ he Educational Goals for Young Australians.pdf

Mills, J. 1989. The Generalist Primary Teacher of Music: A Problem of Confidence. British Journal of Music Education 6(02): 125 - 138. 
Mota, G. 2015. "Twenty-five years of music teacher education in Portugal - revisiting history." In The preparation of music teachers: a Global Perspective, Edited by S. Figueiredo, J. Soares, R.F. Schambeck. 241-264. Florianópolis: UDESC (Grupo de Pesquisa Música e Educação).

Orland-Barak, L. 2014. "Mediation in Mentoring: A Synthesis of Studies". Teaching and Teacher Education 44: 180-188.

Parliament of Victoria, Education and Training Committee 2013. Inquiry into the extent, benefits and potential of music education in Victorian schools. Melbourne: Victorian Government Printer.

Powell, S.R. 2018. "Structure and agency in novice music teaching" Research Studies in Music Education. Published online 8 October, 2018 https://doi.org/10.1177/1321103X18794514

Reese, J., 2016. "Virtual Mentoring of Preservice Teachers: Mentors' Perceptions." Journal of Music Teacher Education 25 (3): 39-52.

Rhodes, C., and S. Fletcher. 2013. "Coaching and Mentoring for Self-Efficacious Leadership in Schools." International Journal of Mentoring and Coaching in Education 2 (1): 47-63.

Richter, D., M. Kunter, O. Lüdtke, U. Klusmann, Y. Anders, and J. Baumert. 2013. "How Different Mentoring Approaches Affect Beginning Teachers' Development in the First Years of Practice." Teaching and Teacher Education 36: 166-177.

Ruddock, E., and S. Leong. 2005. "I am Unmusical! The Verdict of Self-Judgement." International Journal of Music Education 23 (9): 9-22.

Saldaña, J. 2014. "Coding and analysis strategies." In Oxford Handbook of Qualitative Research, edited by P. Leavy, 581-605. Oxford: Oxford University Press.

Saunders, J., Knight, J., Hobsbaum, A., Himonides, E., \& Welch, G.F. (2014). 'Literacy through music' - a multidisciplinary and multi-layered creative collaboration. In M.Barrett (Ed.) Collaborative Creative Thought and Practice in Music. (pp253-268). Farnham: Ashgate Press.

Schmidt, M. 2008. "Mentoring and Being Mentored: The Story of a Novice Music Teacher's Success." Teaching and Teacher Education 24: 635-648.

Schmidt, M., and J. Canser. 2006. "Clearing the Fog: Constructing Shared Stories of a Novice Teacher's Journey." Research Studies in Music Education 27: 55-68.

Seddon, F., and Biasutti, M. (2008). Non-music specialist trainee primary school teachers' confidence in teaching music in the classroom. Music Education Research, 10(3): 403-421.

Smith, M. V. 2005. "Modern Mentoring: Ancient Lessons for Today." Music Educators Journal 92(2): 62-67.

Smith, T. M., and R. M. Ingersoll. 2004. "What are the Effects of Induction and Mentoring on Beginning Teacher Turnover?" American Educational Research Journal 41 (3): 681 - 714.

Stakelum, M. 2008. "Creating a musical world in the classroom: application of a Bourdieuan approach towards understanding teacher practice." British Journal of Music Education, 25(1), 91-102.

Stunell, G. 2006. "The Policy Context of Music in English Primary Schools: How Politics Didn't Help Music." Research Studies in Music Education 26 (2): 2-21.

Sundli, L. 2007. “Mentoring: A New Mantra for Education?" Teaching and Teacher Education 23: 201-214. 
Swain, N., and S. Bodkin-Allen. 2017. "Developing Singing Confidence in Early Childhood Teachers Using Acceptance and Commitment Therapy and Group Singing: A Randomized Trial." Research studies in Music Education 39 (1): 109-120.

Welch, G.F., and Bowmer, A. (2017). 'Music for Change' An action-research, two-year, multidisciplinary collaboration between musicians and Speech and Language Therapists. London: Creative Futures.

Welch, G. F., and J. Henley. 2014. "Addressing the Challenges of Teaching Music by Generalist Primary School Teachers." Revista da ABEM, 22(32).

http://www.abemeducacaomusical.com.br/revistas/revistaabem/index.php/revistaabem/articl e/view/459

\section{Notes on contributors}

Margaret S. Barrett Combined Professor Margaret Barrett Phd is Founding Director of the Creative Collaboratorium at The University of Queensland. She has served as President of the International Society for Music Education (20122014), Chair of the World Alliance for Arts Education (2013-2015), the Asia-Pacific Symposium for Music Education Research (2009-2011), Board member of the International Society for Music Education (2008-2010), and National President of the Australian Society for Music Education (1999-2001). Her research investigates the role of Music and the Arts in human cognition and social and cultural development including: the meaning and value of Arts engagement for young people, young children's musical thinking, young children's identity work in and through music, teaching and learning practices in the arts, and the pedagogy and practice of creativity. This research has been funded by grants from the Australian Research Council, the Australia Council for the Arts, the British Council, and a number of commissioning bodies.

Dr Katie Zhukov is Research Fellow at the School of Music, University of Queensland, Australia, where she has developed evidence-based pedagogical approaches for enhancing music sight-reading skills. Her publications demonstrate a strong record of interdisciplinary approach across music education, psychology and science, and include topics such as teaching and learning in the studio setting, including gender issues, innovative approaches to teaching of music sightreading, skills for classical music careers, performance anxiety and eye movement during music sightreading. Zhukov has published 18 journal articles in high impact international journals such as Journal of Eye Movement Research, Music \& Science, Musicae Scientiae, Psychology of Music, Medical Problems of Performing Artists, International Journal of Music Education, British Journal of Music Education, Music Education Research, Research Studies in Music Education, Teaching and Teacher Education, Australian Journal of Music Education, and also four book chapters.

Professor Graham F. Welch PhD holds the UCL Institute of Education Established Chair of Music Education. He is a Past President of the International Society for Music Education (ISME) (2008-2014) and elected Chair of the internationally based Society for Education, Music and Psychology Research (SEMPRE). He holds Visiting Professorships at universities in the UK and overseas, and is a former member of the UK Arts and Humanities Research Council (AHRC) Review College for Music (2007-2015). Publications number approximately three hundred and fifty and embrace musical development and music education, music and general teacher education, the psychology of music, singing and voice science, and music in special education and disability. New publications include an updated Oxford Handbook of Music Education (2018) and the Oxford Handbook of Singing (2019). He is also co-editing with Pro- fessor Margaret Barrett (The University of Queensland) the forthcoming Oxford Handbook of Early Childhood Music Learning and Development.

\section{ORCID}

Margaret S. Barrett http://orcid.org/0000-0001-5904-9915 Graham F. Welch http://orcid.org/0000-0003-2258-8039 
i The Federal funding has been extended through to 2019 with contributions from the relevant State Departments of Education. Schools now contribute funding to the program which provides for teacher release to enable generalist early childhood teachers with time for consultation and co-planning with their mentor, reflection, and materials preparation. The funding from all sources provides for the administration of the program, mentor training, mentor and teachers being mentored joint workshops, and, teaching release for the specialist music teachers.

ii In one state (anonymous for review) a 2013 Parliamentary Inquiry into music education led to increased funding for music education to schools including to this Mentoring Program through the relevant Department of Education and Training.

iii Ethical permission to undertake the research was obtained from The University of Queensland Human Research Ethics Committee and the relevant state Departments of Education. Third party recruitment was employed to recruit study participants. The researchers were commissioned by the relevant funding body to undertake an evaluation of the program's effectiveness for students, teachers, and schools.

iv The Australian Bureau of Statistics defines socio-economic advantage and disadvantage as "people's access to material and social resources, and their ability to participate in society" (ABS 2016). For example, people living in advantaged areas are typically middle-aged, have high levels of education, work in highly skilled professions and have a median weekly income of AU\$2,640. By contrast, people residing in disadvantaged areas tend to be young, renting and have a median income of only AU\$775 (ABS 2016). 